\title{
Marinobacter salsuginis sp. nov., isolated from the brine-seawater interface of the Shaban Deep, Red Sea
}

\author{
André Antunes, ${ }^{1}$ Luis França, ${ }^{1}$ Fred A. Rainey, ${ }^{2}$ Robert Huber, ${ }^{3}$ \\ M. Fernanda Nobre, ${ }^{4}$ Katrina J. Edwards ${ }^{5}$ and Milton S. da Costa ${ }^{1,6}$ \\ ${ }^{1}$ Laboratório de Microbiologia, Centro de Neurociências e Biologia Celular, \\ Universidade de Coimbra, 3004-517 Coimbra, Portugal \\ ${ }^{2}$ Department of Biological Sciences, Louisiana State University, Baton Rouge, LA 70803, USA \\ ${ }^{3}$ Lehrstuhl für Mikrobiologie und Archaeenzentrum, Universität Regensburg, \\ D-93053 Regensburg, Germany \\ ${ }^{4}$ Departamento de Zoologia, Universidade de Coimbra, 3004-517 Coimbra, Portugal \\ ${ }^{5}$ Department of Biological Sciences, Division of Marine \& Environmental Biology, \\ University of Southern California, Los Angeles, CA 90089-0271, USA \\ ${ }^{6}$ Departamento de Bioquímica, Universidade de Coimbra, 3001-401 Coimbra, Portugal
}

Two moderately halophilic Gram-negative bacteria were isolated from a sample taken from the brine-seawater interface of the Shaban Deep in the Red Sea. Phylogenetic analysis of the 16S rRNA gene sequence showed that these organisms represent a novel species of the genus Marinobacter. Cells of the new isolates formed non-pigmented colonies and were motile by means of a single polar flagellum. Strains SD-14B ${ }^{\top}$ and SD-14C grew optimally at $35-37^{\circ} \mathrm{C}$, in $5 \% \mathrm{NaCl}$ and at $\mathrm{pH}$ 7.5-8.0. The organisms were aerobic, but reduced nitrate to nitrogen under anaerobic conditions. Acid was produced from only a few carbohydrates. Ubiquinone 9 was the major respiratory quinone. The major fatty acids of strains SD-14B ${ }^{\top}$ and SD-14C were $C_{16: 0}, C_{18: 1} \omega 9 c$, summed feature $3\left(\mathrm{C}_{16: 1} \omega 6 c / \mathrm{C}_{16: 1} \omega 7 c\right)$ and $\mathrm{C}_{12: 0} 3-\mathrm{OH}$. The DNA G $+\mathrm{C}$ contents were 55.9 and $55.7 \mathrm{~mol} \%$, respectively. On the basis of the phylogenetic analyses and physiological and biochemical characteristics, it is proposed that strains SD-14B ${ }^{\top}$ and SD-14C represent a novel species of the genus Marinobacter, with the name Marinobacter salsuginis sp. nov. The type strain is strain SD-14B $\mathrm{B}^{\top}\left(=\mathrm{DSM} 18347^{\top}=\mathrm{LMG} 23697^{\top}\right)$.

Several brine-filled deeps are present in the Red Sea. The water in the deeps is extremely saline and anoxic and welldefined brine-seawater interfaces are present, typically with steep gradients of salinity, temperature, density, $\mathrm{O}_{2}$ and $\mathrm{pH}$. The density gradient created at the brine-seawater interface also acts as an in situ particle trap for organic and inorganic materials from the seawater (Eder et al., 2002; Ryan et al., 1969; Scholten et al., 2000). Such interfaces thus represent unique and highly peculiar environments, constituting a very specific biotope that might harbour extensive microbial diversity, as suggested by recent studies (Antunes et al., 2003; Eder et al., 1999, 2001, 2002).

New samples for microbiological studies were retrieved from the northern-most brine-filled deeps of the Red Sea during RV Meteor Cruise M 52/3 in 2002 (Antunes, 2003).

The GenBank/EMBL/DDBJ accession number for the 16S rRNA gene sequence of strain $\mathrm{SD}-14 \mathrm{~B}^{\top}$ is EF028328.
As a result of a subsequent microbial diversity assessment study, focusing on the brine-seawater interface of the Shaban Deep, we obtained several isolates, two of which were assigned to the genus Marinobacter based on 16S rRNA gene sequence analysis. This genus, belonging to the Gammaproteobacteria, currently comprises 15 species with validly published names: Marinobacter algicola, Marinobacter aquaeolei [later heterotypic synonym of Marinobacter hydrocarbonoclasticus (Márquez \& Ventosa, 2005)], Marinobacter bryozoorum, Marinobacter daepoensis, Marinobacter excellens, Marinobacter flavimaris, Marinobacter gudaonensis, Marinobacter hydrocarbonoclasticus, Marinobacter koreensis, Marinobacter lipolyticus, Marinobacter litoralis, Marinobacter lutaoensis, Marinobacter maritimus, Marinobacter sediminum and Marinobacter vinifirmus (Gauthier et al., 1992; Gorshkova et al., 2003; Green et al., 2006; Gu et al., 2007; Kim et al., 2006; Liebgott et al., 2006; Martín et al., 2003; Romanenko et al., 2005; Shieh et al., 2003; Shivaji et al., 2005; Yoon et al., 2003, 2004). In this study we present physiological, biochemical and 
phylogenetic data to show that isolates SD-14B ${ }^{\mathrm{T}}$ and SD-14C represent a novel taxon for which we propose the name Marinobacter salsuginis sp. nov.

Strains SD-14B ${ }^{\mathrm{T}}$ and $\mathrm{SD}-14 \mathrm{C}$ were isolated from samples from the Shaban Deep, Red Sea, during Meteor Cruise M $52 / 3$, in 2002. Enrichment cultures were established from sample SD-14 $\left(15.2 \% \mathrm{NaCl}, \mathrm{pH} 6.0,23.8^{\circ} \mathrm{C}\right.$ in situ temperature), collected at a depth of $1327 \mathrm{~m}$ from the brineseawater interface of the eastern basin $\left(26^{\circ} 12.7^{\prime} \mathrm{N} 35^{\circ} 21.5^{\prime}\right.$ E). Tubes (capacity $28 \mathrm{ml}$ ) were filled with $10 \mathrm{ml}$ Marine broth 2216 (Difco), inoculated with $0.2 \mathrm{ml}$ of the original sample and incubated at $30^{\circ} \mathrm{C}$. When turbidity was observed (after approximately 1 week), the cultures were streaked on Marine agar. The cultures were purified by subculture using the same medium and the isolates were stored at $-70{ }^{\circ} \mathrm{C}$ in growth medium with $15 \%(\mathrm{w} / \mathrm{v})$ glycerol. Thermus medium with $5 \% \mathrm{NaCl}$ (Williams \& da Costa, 1992) was used for the majority of the tests because of the high turbidity of Marine broth and the consequent difficulty in recording results. The type strains of $M$. algicola (DSM 16394 ${ }^{\mathrm{T}}$ ), M. bryozoorum (DSM $15401^{\mathrm{T}}$ ), M. daepoensis (DSM 16072 $), M$. excellens (CIP 107686 ${ }^{\mathrm{T}}$ ), M. flavimaris (DSM $16070^{\mathrm{T}}$ ), M. hydrocarbonoclasticus (DSM $8798^{\mathrm{T}}$ ), M. litoralis (CIP $108099^{\mathrm{T}}$ ), M. lipolyticus (DSM $\left.15157^{\mathrm{T}}\right)$, M. lutaoensis $\left(\mathrm{CIP} 108251^{\mathrm{T}}\right)$, M. maritimus (CIP $108870^{\mathrm{T}}$ ) and M. sediminum (DSM $15400^{\mathrm{T}}$ ) were used for comparative purposes.

Unless stated otherwise, all morphological examinations and biochemical and tolerance tests were performed as described previously (Santos et al., 1989; Nunes et al., 1992) using Thermus liquid medium and Thermus agar containing $5 \%(\mathrm{w} / \mathrm{v}) \mathrm{NaCl}$ at $\mathrm{pH} 7.5$, with incubation at $37^{\circ} \mathrm{C}$ for up to 5 days. The $\mathrm{NaCl}$ range for growth of the organisms was determined in liquid medium containing $0-20 \%(\mathrm{w} / \mathrm{v})$ $\mathrm{NaCl}$, in a reciprocal shaker. The temperature range for growth was determined using the same medium at $10-50{ }^{\circ} \mathrm{C}$. The $\mathrm{pH}$ range for growth was determined at $37^{\circ} \mathrm{C}$ using the same medium with $50 \mathrm{mM}$ MES, HEPES, TAPS, CAPSO and CAPS at $\mathrm{pH} 6-10$.

Single carbon source assimilation tests were performed using a minimal medium composed of Thermus basal salts containing $5 \%(\mathrm{w} / \mathrm{v}) \mathrm{NaCl}$ to which filter-sterilized ammonium chloride $(0.05 \%, \mathrm{w} / \mathrm{v})$ and the carbon source $(0.1 \%, w / v)$ were added. Growth of the strains was examined by measuring the turbidity of cultures incubated at $37^{\circ} \mathrm{C}$ in $20 \mathrm{ml}$ screw-capped tubes containing $10 \mathrm{ml}$ medium for up to 5 days. The same procedure was used to test degradation of aliphatic hydrocarbons, but the cultures were incubated for up to 3 weeks. Acid production and enzymic tests were performed using the API $50 \mathrm{CHB} / \mathrm{E}$ system and API ZYM test strips (bioMérieux), respectively, as recommended by the manufacturer, but with the salinity adjusted to $5 \%(\mathrm{w} / \mathrm{v})$ $\mathrm{NaCl}$ and incubation at $37^{\circ} \mathrm{C}$ for up to 5 days. The ability of the strains to grow with several electron acceptors was examined using Thermus basal salts containing $5 \%(\mathrm{w} / \mathrm{v})$ $\mathrm{NaCl}$ at $37^{\circ} \mathrm{C}$ and $\mathrm{pH}$ 7.5. Pyruvate and glucose $(30 \mathrm{mM})$ were used as electron donors to examine growth under an $\mathrm{N}_{2}$ atmosphere, coupled to the reduction of nitrate, nitrite, sulfate, thiosulfate, sulfur and Fe(III) (each at $10 \mathrm{mM}$, except nitrite which was at $1.0 \mathrm{mM}$ ). Control cultures without an electron acceptor were also tested for growth.

Lipoquinones were extracted from freeze-dried cells and purified by TLC as described by Tindall (1989). Cultures for fatty acid analysis were grown on Marine agar, containing $5.0 \%(\mathrm{w} / \mathrm{v}) \mathrm{NaCl}$, in sealed plastic bags submerged in a waterbath at $37^{\circ} \mathrm{C}$ for $48 \mathrm{~h}$. Extraction, identification and quantification of the fatty acid methyl esters, as well as numerical analysis of the fatty acid profiles, were performed by using the standard MIS library Generation software (Microbial ID).

DNA for the determination of the $\mathrm{G}+\mathrm{C}$ content was isolated as described by Nielsen et al. (1995). The G + C content of the DNA was determined by using HPLC, as described by Mesbah et al. (1989). Extraction of genomic DNA for $16 \mathrm{~S}$ rRNA gene sequence determination, PCR amplification of the 16S rRNA gene and sequencing of the purified PCR products were carried out as described previously (Rainey et al., 1996). Purified products were electrophoresed using a model 310 Genetic Analyzer (Applied Biosystems). The $16 \mathrm{~S}$ rRNA gene sequences were aligned with representative reference sequences of members of the genus Marinobacter and related taxa using MEGA version 3.1 (Kumar et al., 2004). The method of Jukes \& Cantor (1969) was used to calculate evolutionary distances. Phylogenetic dendrograms and bootstrap analyses were generated using various algorithms contained in the PHYLIP package (Felsenstein, 1993).

$16 \mathrm{~S}$ rRNA gene sequence analysis revealed that strains SD-14B ${ }^{\mathrm{T}}$ and SD-14C were members of the Gammaproteobacteria, being most closely related to species of the genus Marinobacter (93.3-98.0\% pairwise 16S rRNA gene sequence similarity). The $16 \mathrm{~S}$ rRNA gene sequences of strains SD-14B ${ }^{\mathrm{T}}$ and SD-14C were identical. These $16 \mathrm{~S}$ rRNA gene sequences showed highest similarity to those of $M$. algicola (97.9\%), M. flavimaris (97.8\%), M. lipolyticus (97.6\%) and M. sediminum (97.6\%). Fig. 1 shows the equidistant branching of these species, which was supported by low bootstrap values $(<50 \%)$.

The results of the physiological and chemotaxonomic characterizations are given in Table 1 and in the species description. Several physiological and biochemical characteristics distinguished strains SD-14B $\mathrm{B}^{\mathrm{T}}$ and SD-14C from the type strains of other species of the genus Marinobacter (Table 1). For example, the new isolates were able to grow on glucose and glycerol but were not able to use the other carbohydrates and polyols examined. On the other hand, the organism used the majority of the organic acids tested but only a few amino acids. Some of the aliphatic hydrocarbons examined, namely n-hexadecane, dodecane, n-decane, heptane, hexane and petroleum ether, were assimilated by strains SD-14B ${ }^{\mathrm{T}}$ and SD-14C. Interestingly, petroleum-impregnated sediments have been retrieved 


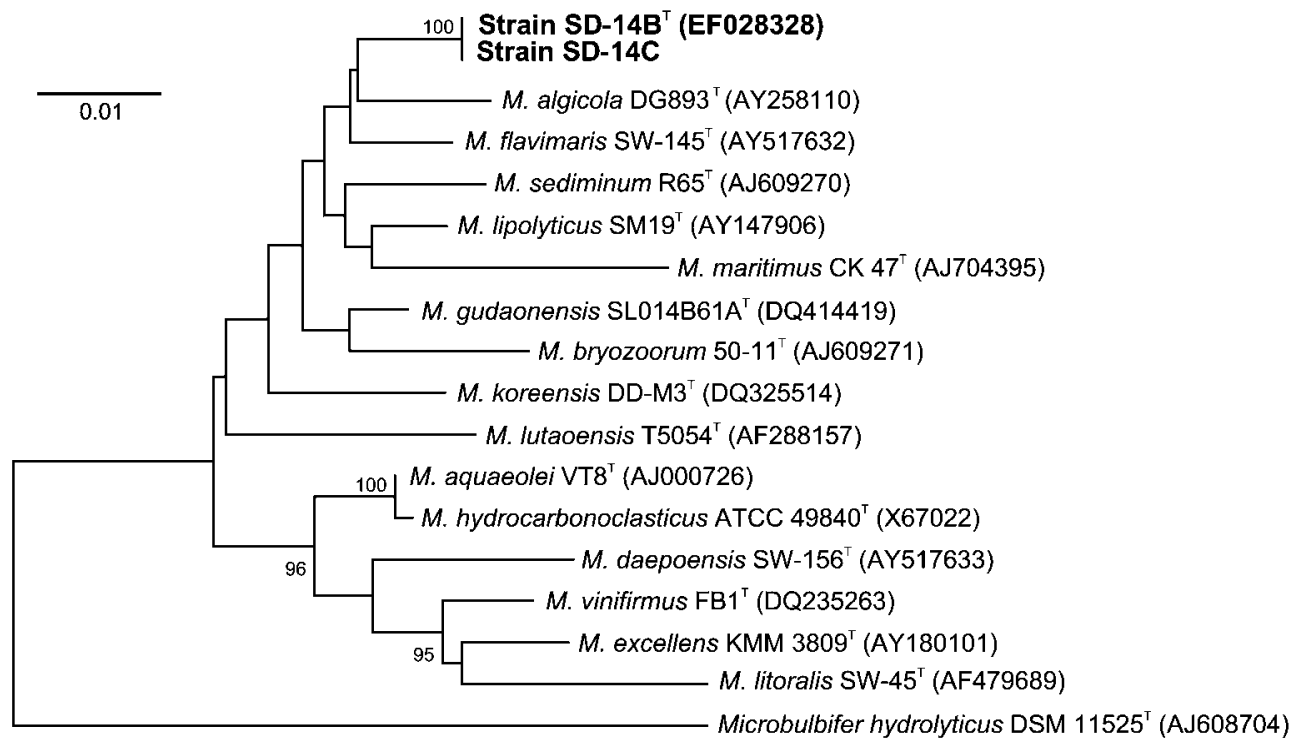

Fig. 1. Phylogenetic dendrogram based on $16 \mathrm{~S}$ rRNA gene sequence comparisons. The dendrogram was reconstructed from evolutionary distances using the neighbour-joining method. Bar, 1 inferred nucleotide substitution per 100 nucleotides. Microbulbifer hydrolyticus DSM $11525^{\top}$ was used as an outgroup.

Table 1. Characteristics that distinguish strain SD-14B ${ }^{\top}$ (Marinobacter salsuginis sp. nov.) from phylogenetically related species

Data were obtained from Green et al. (2006), Kim et al. (2006), Yoon et al. (2004) and this study. All taxa degraded Tween 80, were unable to use sucrose or D-mannose and contained ubiquinone 9. + , Positive; -, negative; $\mathrm{W}$, weak reaction; ND, not determined.

\begin{tabular}{|lccc|}
\hline Characteristic & Strain SD-14B ${ }^{\mathbf{T}}$ & M. algicola & M. flavimaris \\
\hline Temperature range (optimum) for growth $\left({ }^{\circ} \mathrm{C}\right)$ & $10-45(35-37)$ & $5-40(25-30)$ & $4-45(37)$ \\
NaCl range (optimum) for growth $(\%)$ & $1-20(5)$ & $1-9(3-6)$ & $1-20(2-6)$ \\
Presence of: & & & - \\
Valine arylamidase & $\mathrm{W}$ & $\mathrm{ND}$ & - \\
Cystine arylamidase & $\mathrm{W}$ & $\mathrm{ND}$ & - \\
Degradation of: & & - & - \\
Casein & + & + & - \\
Gelatin & + & $\mathrm{ND}$ & - \\
Starch & - & & - \\
Fermentation of D-glucose & + & + & + \\
Utilization of: & & + & - \\
D-Glucose & + & + & - \\
D-Fructose & - & + & - \\
Glycerol & + & + & - \\
Citric acid & - & + & - \\
L-Alanine & + & + & + \\
L-Glutamate & + & - & - \\
n-Hexadecane & + & - & \\
Nitrate reduction & + & 57.0 & \\
Nitrite reduction & + & & \\
DNA G+C content (mol\%) & 55.9 & & \\
\hline
\end{tabular}


previously from the Shaban Deep (Michaelis et al., 1990), which could serve as carbon sources for these organisms. The utilization of aliphatic hydrocarbons has also been reported for other species of this genus, with some minor differences being observed in the assimilation profiles.

Ubiquinone 9 was the major respiratory quinone. The fatty acids of strains SD-14B ${ }^{\mathrm{T}}$ and SD-14C and their relative proportions were consistent with the inclusion of the strains within the genus Marinobacter. A standardized analysis of the fatty acid methyl ester profiles of recognized species of the genus Marinobacter was performed to assess small differences among the organisms. Interestingly, a good correlation was observed between data from the phylogenetic and fatty acid methyl ester analyses (data not shown).

The major fatty acids of strains SD-14B ${ }^{\mathrm{T}}$ and SD-14C were $\mathrm{C}_{16: 0}, \mathrm{C}_{18: 1} \omega 9 c$, summed feature $3\left(\mathrm{C}_{16: 1} \omega 6 c / \mathrm{C}_{16: 1} \omega 7 c\right)$ and $\mathrm{C}_{12: 0} 3-\mathrm{OH}$. These fatty acids are also predominant components of other species of the genus Marinobacter and are present in similar relative proportions in most species, except M. bryozoorum (Table 2). However, some differences exist that allow differentiation of many of the species from each other. The fatty acid profile of strains $S D-14 \mathrm{~B}^{\mathrm{T}}$ and SD-14C was very similar to those of the type strains of $M$. sediminum and M. flavimaris, but these organisms could be easily distinguished from each other by physiological and biochemical characteristics.

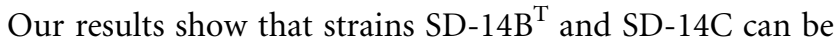
distinguished from other recognized species of the genus Marinobacter. We therefore propose that the two strains represent a novel species, with the name Marinobacter salsuginis sp. nov.

\section{Description of Marinobacter salsuginis sp. nov.}

Marinobacter salsuginis (sal.su'gi.nis. L. gen. n. salsuginis from salt water, brine, pertaining to the environment from which the strain was isolated).

Table 2. Fatty acid compositions (\%) of Marinobacter strains

Strains: 1, SD-14B ${ }^{\mathrm{T}} / \mathrm{SD}-14 \mathrm{C}$ (Marinobacter salsuginis sp. nov.); 2, M. algicola DG893 ${ }^{\mathrm{T}} ; 3$, M. flavimaris $\mathrm{SW}^{-145^{\mathrm{T}}}$; 4, M. sediminum $\mathrm{R}^{\mathrm{T}}{ }^{\mathrm{T}}$; 5,

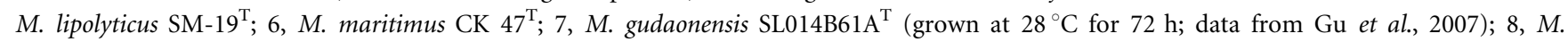

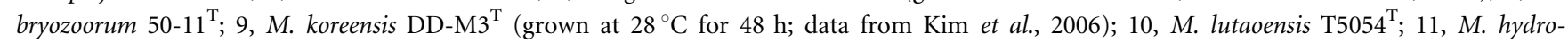
carbonoclasticus SP. $17^{\mathrm{T}} ; 12$, M. daepoensis SW-156 $; 13$, M. excellens KMM $3809^{\mathrm{T}} ; 14$, M. litoralis SW- $45^{\mathrm{T}}$. Values for fatty acids present at levels of less than $0.5 \%$ are not shown.

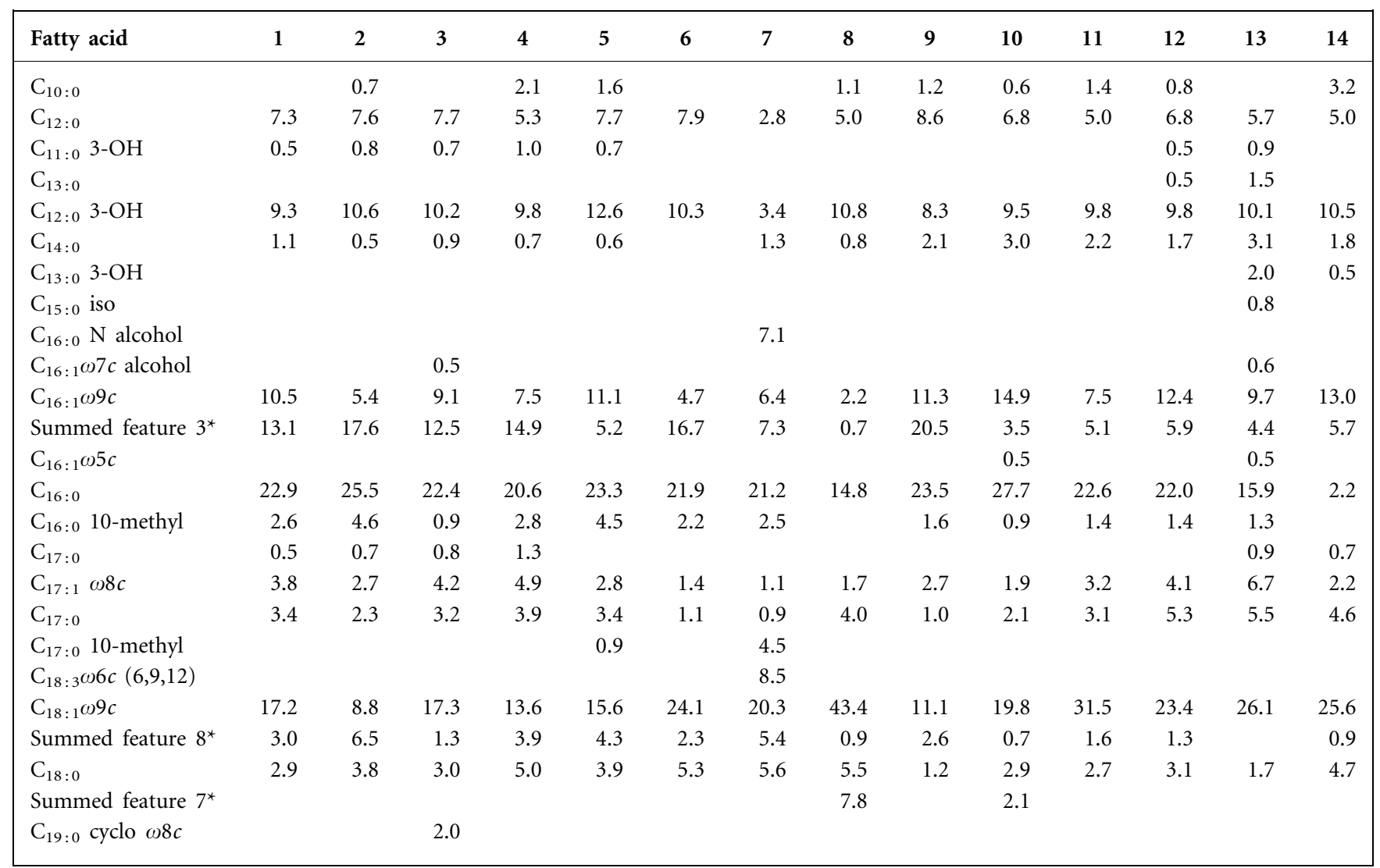

${ }^{*}$ Summed features: $3, \mathrm{C}_{16: 1} \omega 6 c / \mathrm{C}_{16: 1} \omega 7 c ; 7, \mathrm{C}_{19: 0}$ cyclo $\omega 10 c / \mathrm{C}_{19: 1} \omega 6 c ; 8, \mathrm{C}_{18: 1} \omega 6 c / \mathrm{C}_{18: 1} \omega 7 c$. 
Gram-negative, non-spore-forming, rod-shaped cells $(1 \mu \mathrm{m}$ in width and $2-4 \mu \mathrm{m}$ in length). Motile by means of a single polar flagellum. Colonies on Marine agar are round and whitish $(2-3 \mathrm{~mm}) . \mathrm{NaCl}$ is required for growth; the $\mathrm{NaCl}$ range for growth is $1-20 \%(\mathrm{w} / \mathrm{v})$, with optimum growth occurring at about $5 \%(\mathrm{w} / \mathrm{v}) \mathrm{NaCl}$. Growth occurs at $10-45^{\circ} \mathrm{C}$ (optimum, $35-37^{\circ} \mathrm{C}$ ). $\mathrm{pH}$ range for growth is about 6.5-9.5 (optimum, pH 7.5-8.0). Heterotrophic and facultatively anaerobic. Grows without yeast extract or growth factors. Produces acid from glycerol, D-glucose, D-fructose and 5-ketogluconate; acid is not produced from D-melibiose, D-lactose, maltose or mannitol or any of the other substrates tested. Denitrifies in medium supplemented with pyruvate or D-glucose. Oxidase- and catalase-positive. Gelatin, casein and Tweens 20, 40, 60 and 80 are hydrolysed. Arbutin, DNA, aesculin, hippurate, starch and xylan are not hydrolysed. Acetate, glucose, lactate, malate, fumarate, glycerol, L-alanine, L-glutamate, L-glutamine, L-phenylalanine, proline, pyruvate, succinic acid and 2-oxoglutarate are assimilated. Fructose, galactose, mannose, L-sorbose, L-rhamnose, ribose, xylose, L-arabinose, maltose, lactose, cellobiose, melezitose, raffinose, sucrose, ribitol, sorbitol, arabitol, mannitol, erythritol, xylitol, glucuronate, citrate, formic acid, glycine, aspartate, arginine, asparagine, histidine, lysine, methionine, serine, tryptophan, ethanol, benzoate and methanol are not used. Aliphatic hydrocarbons used include n-decane, n-hexadecane, heptane, hexane and petroleum ether, but L-chlorobutane, dodecane and toluene are not used. Alkaline phosphatase, esterase (C4), esterase lipase (C8), lipase (C14), leucine arylamidase, naphthol-ASBI-phosphohydrolase and $N$-acetyl- $\beta$-glucosaminidase are detected. Weak reactions are also detected for valine arylamidase, cystine arylamidase and acid phosphatase. Major cellular fatty acids are $\mathrm{C}_{16: 0}, \mathrm{C}_{18: 1} \omega 9 c$, summed feature 3 $\left(\mathrm{C}_{16: 1} \omega 6 c / \mathrm{C}_{16: 1} \omega 7 c\right)$ and $\mathrm{C}_{12: 0} 3-\mathrm{OH}$. Ubiquinone 9 is the major isoprenoid quinone. The DNA G $+\mathrm{C}$ content of the type strain is $55.9 \mathrm{~mol} \%$.

Strains SD- $14 \mathrm{~B}^{\mathrm{T}}$ and SD-14C were isolated from the brineseawater interface of the Shaban Deep, Red Sea. The type strain is $\mathrm{SD}-14 \mathrm{~B}^{\mathrm{T}}\left(=\mathrm{DSM} 18347^{\mathrm{T}}=\mathrm{LMG} 23697^{\mathrm{T}}\right)$.

\section{Acknowledgements}

We are grateful for the valuable help of the scientists and crew on board RV Meteor (Cruise M 52/3). We also thank M. Taborda for technical assistance. This work was supported financially by the Deutsche Forschungsgemeinschaft (DFG HU 711/2-1 and HU 711/2-2), Fundação para a Ciência e a Tecnologia (POCI/BIA-BDE/56014/ 2004) and the Governor's Biotechnology Initiative of the Louisiana Board of Regents (BOR number 021 - Moving an Established Marine Biotechnology Programme to the Next Level: Natural Product Screening and Development). The work of A. A. was supported by a post-doctoral scholarship from Fundação para a Ciência e a Tecnologia (SFRH/BPD/22576/2005). The work of L.F. was supported by the Fundação para a Ciência e a Tecnologia and FEDER (project A005/ 2005, Action V.5.1.).

\section{References}

Antunes, A. (2003). Microbial life at the anaerobic brine/seawater and sediment/brine interfaces, In Black Sea-Mediterranean-Red Sea, Cruise No. 52, January 2-March 27, 2002, pp. 50-52. Edited by J. Pätzold, G. Bohrmann \& C. Hübscher. Hamburg, Germany: Universität Hamburg.

Antunes, A., Eder, W., Fareleira, P., Santos, H. \& Huber, R. (2003). Salinisphaera shabanensis gen. nov., sp. nov., a novel, moderately halophilic bacterium from the brine-seawater interface of the Shaban Deep, Red Sea. Extremophiles 7, 29-34.

Eder, W., Ludwig, W. \& Huber, R. (1999). Novel 16S rRNA gene sequences retrieved from highly saline brine sediments of Kebrit Deep, Red Sea. Arch Microbiol 172, 213-218.

Eder, W., Jahnke, L. L., Schmidt, M. \& Huber, R. (2001). Microbial diversity of the brine-seawater interface of the Kebrit Deep, Red Sea, studied via $16 \mathrm{~S}$ rRNA gene sequences and cultivation methods. Appl Environ Microbiol 67, 3077-3085.

Eder, W., Schmidt, M., Koch, M., Garbe-Schönberg, D. \& Huber, R. (2002). Prokaryotic phylogenetic diversity and corresponding geochemical data of the brine-seawater interface of the Shaban Deep, Red Sea. Environ Microbiol 4, 758-763.

Felsenstein, J. (1993). PHYLIP (phylogeny inference package), version 3.5.1. Department of Genome Sciences, University of Washington, Seattle, USA.

Gauthier, M. J., Lafay, B., Christen, R., Fernandez, L., Acquaviva, M., Bonin, P. \& Bertrand, J. C. (1992). Marinobacter hydrocarbonoclasticus gen. nov., sp. nov., a new, extremely halotolerant, hydrocarbondegrading marine bacterium. Int J Syst Bacteriol 42, 568-576.

Gorshkova, N. M., Ivanova, E. P., Sergeev, A. F., Zhukova, N. V., Alexeeva, Y., Wright, J. P., Nicolau, D. V., Mikhailov, V. V. \& Christen, R. (2003). Marinobacter excellens sp. nov., isolated from sediments of the Sea of Japan. Int J Syst Evol Microbiol 53, 2073-2078.

Green, D. H., Bowman, J. P., Smith, E. A., Gutierrez, T. \& Bolch, C. J. S. (2006). Marinobacter algicola sp. nov., isolated from laboratory cultures of paralytic shellfish toxin-producing dinoflagellates. Int J Syst Evol Microbiol 56, 523-527.

Gu, J., Cai, H., Yu, S.-L., Qu, R., Yin, B., Guo, Y.-F., Zhao, J.-Y. \& Wu, X.-L. (2007). Marinobacter gudaonensis sp. nov., isolated from an oil-polluted saline soil in a Chinese oilfield. Int J Syst Evol Microbiol 57, 250-254.

Jukes, T. H. \& Cantor, C. R. (1969). Evolution of protein molecules. In Mammalian Protein Metabolism, pp. 21-132. Edited by H. N. Munro. New York: Academic Press.

Kim, B.-Y., Weon, H.-Y., Yoo, S.-H., Kim, J.-S., Kwon, S.-W., Stackebrandt, E. \& Go, S.-J. (2006). Marinobacter koreensis sp. nov., isolated from sea sand in Korea. Int J Syst Evol Microbiol 56, 2653-2656.

Kumar, S., Tamura, K. \& Nei, M. (2004). MEGA3: integrated software for molecular evolutionary genetics analysis and sequence alignment. Brief Bioinform 5, 150-163.

Liebgott, P.-P., Casalot, L., Paillard, S., Lorquin, J. \& Labat, M. (2006). Marinobacter vinifirmus sp. nov., a moderately halophilic bacterium isolated from a wine-barrel-decalcification wastewater. Int J Syst Evol Microbiol 56, 2511-2516.

Márquez, M. C. \& Ventosa, A. (2005). Marinobacter hydrocarbonoclasticus Gauthier et al. 1992 and Marinobacter aquaeolei Nguyen et al. 1999 are heterotypic synonyms. Int J Syst Evol Microbiol 55, 1349-1351.

Martín, S., Marquez, M. C., Sánchez-Porro, C., Mellado, E., Arahal, D. R. \& Ventosa, A. (2003). Marinobacter lipolyticus sp. nov., a novel moderate halophile with lipolytic activity. Int J Syst Evol Microbiol 53, 1383-1387. 
Mesbah, M., Premachandran, U. \& Whitman, W. B. (1989). Precise measurement of the $\mathrm{G}+\mathrm{C}$ content of deoxyribonucleic acid by highperformance liquid chromatography. Int J Syst Bacteriol 39, 159-167.

Michaelis, W., Jenisch, A. \& Richnow, H. H. (1990). Hydrothermal petroleum generation in Red Sea sediments from the Kebrit and Shaban Deeps. Appl Geochem 5, 103-114.

Nielsen, P., Fritze, D. \& Priest, F. G. (1995). Phenetic diversity of alkaliphilic Bacillus strains: proposal for nine new species. Microbiology 141, 1745-1761.

Nunes, O. C., Donato, M. M. \& da Costa, M. S. (1992). Isolation and characterization of Rhodothermus strains from S. Miguel, Azores. Syst Appl Microbiol 15, 92-97.

Rainey, F. A., Ward-Rainey, N., Kroppenstedt, R. M. \& Stackebrandt, E. (1996). The genus Nocardiopsis represents a phylogenetically coherent taxon and a distinct actinomycete lineage: proposal of Nocardiopsaceae fam. nov. Int J Syst Bacteriol 46, 1088-1092.

Romanenko, L. A., Schumann, P., Rohde, M., Zhukova, N. V., Mikhailov, V. V. \& Stackebrandt, E. (2005). Marinobacter bryozoorum sp. nov. and Marinobacter sediminum sp. nov., novel bacteria from the marine environment. Int J Syst Evol Microbiol 55, 143-148.

Ryan, W. B. F., Thorndike, E. M., Ewing, M. \& Ross, D. A. (1969). Suspended matter in the Red Sea brines and its detection by light scattering. In Hot Brines and Recent Heavy Metal Deposits in the Red Sea, pp. 153-157. Edited by E. Degens \& D. A. Ross. New York: Springer.

Santos, M. A., Williams, R. A. D. \& da Costa, M. S. (1989). Numerical taxonomy of Thermus isolates from hot springs in Portugal. Syst Appl Microbiol 12, 310-315.
Scholten, J. C., Stoffers, P., Garbe-Schönberg, D. \& Moammar, M. (2000). Hydrothermal mineralization in the Red Sea. In Handbook of Marine Mineral Deposits, pp. 369-395. Edited by D. S. Cronan. Boca Raton, FL: CRC Press.

Shieh, W. Y., Jean, W. D., Lin, Y. T. \& Tseng, M. (2003). Marinobacter lutaoensis sp. nov., a thermotolerant marine bacterium isolated from a coastal hot spring in Lutao, Taiwan. Can J Microbiol 49, 244-252.

Shivaji, S., Gupta, P., Chaturvedi, P., Suresh, K. \& Delille, D. (2005). Marinobacter maritimus sp. nov., a psychrotolerant strain isolated from sea water off the subantarctic Kerguelen islands. Int J Syst Evol Microbiol 55, 1453-1456.

Tindall, B. J. (1989). Fully saturated menaquinones in the archaebacterium Pyrobaculum islandicum. FEMS Microbiol Lett 60, 251254.

Williams, R. A. D. \& da Costa, M. S. (1992). The genus Thermus and related microorganisms. In The Prokaryotes, 2nd edn, pp. 3745-3753. Edited by A. Balows, H. G. Trüper, M. Dworkin, W. Harder \& K.-H. Schleifer. New York: Springer.

Yoon, J.-H., Shin, D.-Y., Kim, I.-G., Kang, K. H. \& Park, Y.-H. (2003). Marinobacter litoralis sp. nov., a moderately halophilic bacterium isolated from sea water from the East Sea in Korea. Int J Syst Evol Microbiol 53, 563-568.

Yoon, J.-H., Yeo, S.-H., Kim, I.-G. \& Oh, T.-K. (2004). Marinobacter flavimaris sp. nov. and Marinobacter daepoensis sp. nov., slightly halophilic organisms isolated from sea water of the Yellow Sea in Korea. Int J Syst Evol Microbiol 54, 1799-1803. 